\title{
Effect of cigarette smoking on copper, lead, and cadmium accumulation in human lens
}

\author{
Osman Cekic
}

\begin{abstract}
Aim-To identify cigarette smoking as a risk factor for development of cataract, to determine the importance of copper, lead, and cadmium in cataractogenesis, and to learn about any relation between those elements.

Methods-Copper, lead, and cadmium concentrations were measured by atomic absorption spectrophotometry in 37 cataractous and nine normal human lenses.

Results-All three element accumulations in lenses with cataract were statistically meaningful. Lenticular copper, lead, and cadmium were increased significantly with cigarette smoking. Cadmium had a positive correlation both with lead and copper in cataractous lenses.

Conclusion-The accumulation of copper, lead, and cadmium occurs in cataract. The probable source of cadmium in humans is cigarettes. Lenticular cadmium accumulation also increases copper and lead precipitation in the lens. Cigarette smoking might be cataractogenic.

(Br f Ophthalmol 1998;82:186-188)
\end{abstract}

Cataract is responsible for visual impairment in 30 million to 45 million people and is the largest single cause of blindness worldwide. ${ }^{1}$ At least 5 million to 10 million new, visually disabling cataracts occur yearly around the world. ${ }^{2}$ From a clinical standpoint, cataract is defined as visual impairment as a result of a disturbance of lens transparency. However, although small opacities which do not fall within the visual axis have little effect on visual acuity, any source of light scattering can be considered a cataractogenic lesion from a biochemical standpoint. ${ }^{1}$

Senile cataracts probably result from many, possibly compound, obscure causes. Race, altitude, dietary habits, aging, diabetes, cardiovascular disease, cigarette smoking, use of topically applied ophthalmic drugs, environmental factors, occupation, exposure to sunlight, low socioeconomic status are some that have been suggested. ${ }^{1-3}$

A potential role of cigarette smoking in development of cataract has been established by a series of epidemiological studies, first in Edinburgh, ${ }^{3}$ then Oxford, ${ }^{45}$ London, ${ }^{6}$ and the USA. $^{7-10}$

As cataract is an important medical, financial, and social burden, it is particularly important to identify its aetiology and risk factors.

Correspondence to: Osman Cekic, MD, Basak Sokak, No 54/7, 06660 Kucukesat, Ankara, Turkey.

Accepted for publication 18 September 1997 In 37 cataractous ( 25 male and 12 female) and nine normal (five male and four female) human lenses copper, lead, cadmium, and calcium contents were measured with an atomic absorption spectrophotometer. The ages of the cataractous group ranged from 46 to 73 years (mean 54.7 (SD 5.4)) while the control group ranged in age from 51 to 67 (57.7 (3.2)) years. Normal lenses were removed from cadaver eyes within 10 hours after death. The cataractous lens material was obtained by extracapsular lens extraction in patients with a visual acuity of $10 / 100$ or worse. Lenses from cadaver eyes were examined visually and the nuclear parts of the clear ones were included in the study. The lenses were placed into scrupulously cleaned glass pots, and they were kept frozen at temperatures below $-20^{\circ} \mathrm{C}$ until analysis of the elements. Then they were dried in an oven at $90^{\circ} \mathrm{C}$ until a constant weight was reached. Dry weights of all the samples were measured, then they were burned till all their organic parts had been lost. Residual inorganic parts were diluted with distilled water up to a known volume. The copper, lead, and cadmium levels were measured by atomic absorption spectrophotometry (Hitachi 180/80 AAS) by using a standard addition technique and a graphite furnace system. ${ }^{11}$ All the measurements were taken twice. Results were calculated in terms of $\mu \mathrm{g} / \mathrm{g}$ dry tissue weight (ppm).

The results were analysed by Student's $t$ test, and correlation analysis.

All the lens samples were taken from patients who had no metabolic or systemic disease, and who were not taking medication that could interfere with their blood element level.

\section{Results}

The mean concentrations of copper $(\mathrm{Cu})$, lead $(\mathrm{Pb})$, and cadmium (Cd) of normal and cataractous female and male lenses, as determined by the methods described above, are presented in Table 1. For the cataractous lenses, no meaningful difference was noted in the accumulation of copper or lead levels according to the sex differences. The mean concentration of cadmium was significantly higher in males (1.05 (SD 0.18) ppm) than in females $(0.88(0.22) \mathrm{ppm})(\mathrm{p}<0.01)$. While there was no significant difference for normal human lenticular mean copper content, normal lenses also showed higher levels of cadmium in males $(0.055(0.004) \mathrm{ppm})$ than in females $(0.032(0.003) \mathrm{ppm}) \quad(\mathrm{p}<0.05)$. Although there was some lead in cataractous lenses, it could not be detected in normal lenses.

Overall, comparing copper, lead, and cad- 
Table 1 The mean (SD) Cu, Cd, and Pb levels in cataractous and normal human lenses ( $\mu g / g$ dry tissue weight $=p p m$

\begin{tabular}{|c|c|c|c|c|c|c|}
\hline Lenses & $C u$ & No & $C d$ & No & $\mathrm{Pb}$ & No \\
\hline \multicolumn{7}{|l|}{ Cataractous } \\
\hline overall & $2.11(0.47)$ & 37 & $0.99 \quad(0.21)$ & 35 & $5.17(1.43)$ & 34 \\
\hline males & $2.13(0.44)$ & 25 & $1.05 \quad(0.18)$ & 23 & $5.00(1.20)$ & 23 \\
\hline females & $2.04(0.53)$ & 12 & $0.88 \quad(0.22)$ & 12 & $5.53(1.76)$ & 11 \\
\hline $\mathrm{p}$ Values & $>0.05$ & & $<0.01$ & & $<0.1$ & \\
\hline \multicolumn{7}{|l|}{ Normal } \\
\hline overall & $0.69(0.15)$ & 9 & $0.045(0.004)$ & 9 & - & 9 \\
\hline males & $0.66(0.16)$ & 5 & $0.055(0.004)$ & 5 & - & 5 \\
\hline females & $0.72(0.12)$ & 4 & $0.032(0.003)$ & 4 & - & 4 \\
\hline $\mathrm{p}$ Values & $>0.05$ & & $<0.05$ & & - & \\
\hline
\end{tabular}

the elements were higher in the latter group $(\mathrm{p}<0.005, \mathrm{p}<0.0005$, and $\mathrm{p}<0.0005$ respectively).

Among 37 cataractous patients 22 were smokers; they were categorised into two groups according to their habits as follows: 10 of 22 patients who were moderate smokers smoked up to 10 cigarettes per day, 12 of 22 patients who were heavy smokers smoked more than 20 cigarettes per day. All 22 patients had smoked for at least 10 years without interruption. The other 15 cataractous patients had been nonsmokers for at least 10 years. In the 1-10 cigarettes/day group, the copper levels were higher than in the more than 20 cigarettes/day group and in the non-smoker group. Mean cadmium content in heavy smokers (1.19 (SD $0.09) \mathrm{ppm}$ ) was higher than in the moderate (1.01 (0.11) ppm) and non-smoker (0.79 $(0.17) \mathrm{ppm})$ groups $(\mathrm{p}<0.005$ and $\mathrm{p}<0.0005)$. The lead level was also higher in both the smoker groups than in the non-smoker group; it was similar in both moderate and heavy smoker group (Table 2).

When we looked at the correlation coefficients in cataractous and normal lenses, there was a significant positive correlation between copper and cadmium $(\mathrm{p}<0.05)$, and cadmium and lead $(\mathrm{p}<0.05)$ in cataractous lenses (Table 3).

\section{Discussion}

Data suggest a potential role of cigarette smoking in the development of cataract. Smoking for more than 75 pack years was associated with a doubling of the risk of cataract ${ }^{4}$; it was calculated that only $2.6 \%$ of cataracts could be attributed to heavy smoking. ${ }^{12}$ In one study physicians found the relative risk of cataract in smokers of more than 20 cigarettes/day was 2.16 compared with ex-smokers and non-smokers. ${ }^{9}$ In another study, the relative risk for nuclear lens opacity and cigarette smoking ranged from 1.0 for past light smokers to 2.6 for past heavy smokers, to 2.9 for present heavy smokers. ${ }^{6}$ Smoking also appears to increase the risk of cataract in type 2 diabetics. ${ }^{13}$
Table 3 Correlation coefficient values between the elements studied in cataractous and normal human lenses

\begin{tabular}{llll}
\hline Lenses & $\mathrm{Cu}-\mathrm{Cd}$ & $\mathrm{Cu}-\mathrm{Pb}$ & $\mathrm{Cd}-\mathrm{Pb}$ \\
\hline Cataractous & 0.65 & 0.41 & 0.63 \\
Normal & -0.38 & - & - \\
\hline
\end{tabular}

Many studies have linked cataract with smoking, but there is speculation about the mechanism. Smoking appears to induce oxidative stress, in that smokers have diminished level of antioxidants such as vitamin C, vitamin E, and carotenoids. ${ }^{910}$ Cyanide and thiocyanide levels are raised in the blood of smokers, and cigarette smoke is rich in free radicals and aldehydes. ${ }^{14}$ Highly reactive radicals are unlikely to reach the lens, but some aldehydes might find their way to the lens to attack enzymes and other proteins in the same way as isocyanate. ${ }^{15}$ The constituent aromatic compounds and trace metals in smoke condensates generate long lived reactive oxygen species which eventually might cause oxidative damage to the lens and produce cataracts. ${ }^{16}$ Finally, the changes in the cadmium ${ }^{17}$ and some other trace metals in the blood might be responsible for cataractogenesis in smokers. Additionally, cadmium possibly interacts with various components of the lens during the process of cataractogenesis.

Smoking as a source of exposure to cadmium has been recognised for at least 25 years. Investigators found cadmium at 1.56 to 1.96 $\mu \mathrm{g}$ per cigarette. Data showed that $0.1-1.2 \mu \mathrm{g}$ of cadmium might have been inhaled by smoking one cigarette. ${ }^{18}$ In this study, the cadmium concentration was found to be higher in cataractous than in normal lenses, as had previously been reported. ${ }^{19}{ }^{20}$ Ramarkrishnan et al found a significant accumulation of cadmium in both the blood and the lens of smokers. ${ }^{17}$ It is likely that the major source of cadmium is tobacco smoke and the high concentration of cadmium in tobacco leaves probably results from the widespread use of chemical fertilisers. ${ }^{19}$ We found significantly higher cadmium level in cataractous smokers in our study. Data showed an increasing cadmium concentration in the lens with increasing numbers of cigarettes per day.

Cadmium may hasten cataractogenesis by various mechanisms. It is known to compete with copper in the body and could affect the copper homeostasis of blood and copper containing proteins. ${ }^{21}$ Copper is necessary for the normal physiological activity of numerous enzymes such as cytochrome oxidase, superoxide dismutase, and uricase. Derangements in copper metabolism and resulting changes in its concentration within tissues and body fluids have been associated with pathological states. ${ }^{22}$

Table 2 Cataractous lens concentrations (SD) of $\mathrm{Cu}, \mathrm{Cd}$, and $\mathrm{Pb}$ in the groups with different cigarette habits (ppm)

\begin{tabular}{lllllll}
\hline Cigarette habit & $\mathrm{Cu}$ & $\mathrm{No}$ & $\mathrm{Cd}$ & \multirow{2}{*}{$\mathrm{No}$} & $\mathrm{Pb}$ & No \\
\hline 1-10 cigarettes/day (A) & $2.45(0.35)$ & 10 & $1.01(0.11)$ & 10 & $5.66(1.40)$ & 9 \\
More than 20 cigarettes/day (B) & $2.11(0.29)$ & 12 & $1.19(0.09)$ & 12 & $5.90(1.04)$ & 12 \\
Non-smokers (C) & $1.87(0.52)$ & 15 & $0.79(0.17)$ & 13 & $4.24(1.09)$ & 13 \\
p (A-B) & $<0.01$ & & $>0.0005$ & & $<0.10$ & $<0.005$ \\
p (A-C) & $<0005$ & $<0.0005$ & & $<0.0005$ \\
p (B-C) & $<0.05$ & $<0.0005$ & & \\
\hline
\end{tabular}


Numerous investigators have reported alterations in trace metal components of the lens occurring in cataractogenesis. While some reported no correlation between copper and cataract, ${ }^{22}$ some had shown raised, ${ }^{19}{ }^{23-25}$ and some decreased levels of copper in cataractous lenses. ${ }^{20}$ In the present study, we observed raised copper level in the cataractous lenses. There was no significant difference in copper values in relation to both normal and cataractous groups.

Cadmium may directly interact with lens proteins and denature them in cataractogenesis. ${ }^{17}$ It is known that heavy metal ions such as lead can precipitate blood and body proteins. ${ }^{21}$ Lead accumulation in the body is also a result of pollution. ${ }^{19}$ We could not detect lead in normal lenses while it was found in cataractous lenses. This also confirms previous studies. ${ }^{125}$

Lenticular copper and lead was also observed to be significantly higher in smokers. Cadmium accumulation possibly increased the absorption of the other two elements. There were positive correlations between copper and lead with cadmium content in the cataractous lenses. So, it can be hypothesised that raised concentrations of cadmium in smokers might trigger copper and lead accumulation in the lens, or the precipitation of copper and/or lead might also cause the precipitation of cadmium.

Copper, lead, and cadmium accumulation occurs in the cataractous lenses. Current smoking or number of cigarettes smoked per day might be a significant risk factor in cataractogenesis.

1 Paterson CA, Delamere NA. The lens. In: Hart WM, ed. Adler's physiology of the eye. 9th ed. St Louis: Mosby, 1992:348-90.

2 Sommer A. Cataracts as an epidemiologic problem. $A m \mathcal{F}$ Ophthalmol 1977;83:334-9.

3 Clayton RM, Cuthbert J, Duffy J, et al. Some risk factors associated with cataract in SE Scotland: a pilot study. Tran Ophthalmol Soc UK 1982;102:331-6.

4 Harding JJ, van Heyningen R. Drugs, including alcohol, that act as risk factors for cataract, and possible protection against cataract by aspirin-like analgesics and cyclopenthiazide. Br f Ophthalmol 1988;72;809-14.
5 Harding JJ, van Heyningen R. Beer, cigarettes and military work as risk factors for cataract. Dev Ophthalmol 1989;17: 13-6.

6 Flaye DE, Sullivan KN, Cullinan TR, Silver JH, Whitelocke RAF. Cataracts and cigarette smoking. The city eye study. Eye 1989;3:379-84.

7 West S, Munoz B, Emmett EA, Taylor HR. Cigarette smoking and risk of nuclear cataracts. Arch Ophthalmol 1989;107:1166-9.

8 Leske MJ, Chylack LT, Wu S. The lens opacities case-control study. Risk factors for cataract. Arch Ophthalmol 1991;199:244-51.

9 Christen WG, Manson JE, Seddon JM, et al. A prospective study of cigarette smoking and risk of cataract in men. fAMA 1992;268:989-93.

10 Hankinson SE, Willet WC, Colditz GA, et al. A prospective study of cigarette smoking and risk of cataract surgery in women. $7 A M A$ 1992;268:994-8.

11 Kickbright GF. Atomic absorption spectroscopy. Elemental analysis of biological materials. Technical report series No 197. Vienna, International Energy Agency, 1980:141-63.

12 van Heyningen R, Harding JJ. A case-control study of cataract in Oxfordshire: some risk factors. $\mathrm{Br} \mathcal{F}$ Ophthalmol 1988;72:804-8.

13 Klein BEK, Klein R, Moss SE. Prevelance of cataracts in a population-based study of persons with diabetes mellitus. Ophthalmology 1985;92:1191-6.

14 Reznick AZ, Cross CE, Hu M. Modification of plasma proteins by cigarette smoke as measured by protein carbonyl formation. Biochem $\mathcal{F}$ 1992;286:607-11.

15 Harding JJ. Cigarette smoking and risk of cataract. $7 A M A$ 1993;269:747.

16 Balasubramanian D, Shalini VK, Luthra M, et al. Molecular epidemiology of the smoke cataract connection. Oxidant stress mechanism. Invest Ophthalmol Vis Sci 1993; abstract 2925.

17 Ramakrishnan S, Sulochana KN, Selvaraj T, et al. Smoking of beedies and cataract: cadmium and vitamin $\mathrm{C}$ in the lens of beedies and cataract: cadmium and vitamin

18 Frieberg L, Piscator M, Nordberg GF, Kjellstörm T. Cadmium in the environment. 2nd ed. Cleveland: CRC Press, 1974:9-21.

19 Racz P, Erdöhelyi A. Cadmium, lead and copper concentrations in normal and senile cataractous human lenses. Ophthalmic Res 1988;20:10-3.

20 Swanson A, Trusdale AW. Elemental analysis in normal and cataractous human lens tissue. Biochem Biophys Res Commun 1971;45:1488-96.

21 Marklund SL. Superoxide dismutase in human tissue cells and extracellular fluids, clinical implication. Free radicals aging and degenerative disease. New York: Alan R Liss, 1986: 509.

22 Cook CS, Mc Gahan MC. Copper concentration in cornea, iris, normal, and cataractous lenses and intraocular fluids of vertabrates. Curr Eye Res 1986;,5:69-77.

23 Nath R, Srivastava SK, Singh K. Copper levels in human cataract lens. Ind F Exp Biol 1969;7:25-8.

24 Balaji M, Sasikala K, Ravindran T. Copper levels in human mixed, nuclear brunescance, and posterior subcapsular cataract. Br f Ophthalmol 1992;76:668-9.

25 Shukla N, Moitra JK, Triverdi RC. Determination of lead, zinc, potassium, calcium, copper, and sodium in human cataract lenses. Sci Total Environ 1996;181:161-5. 